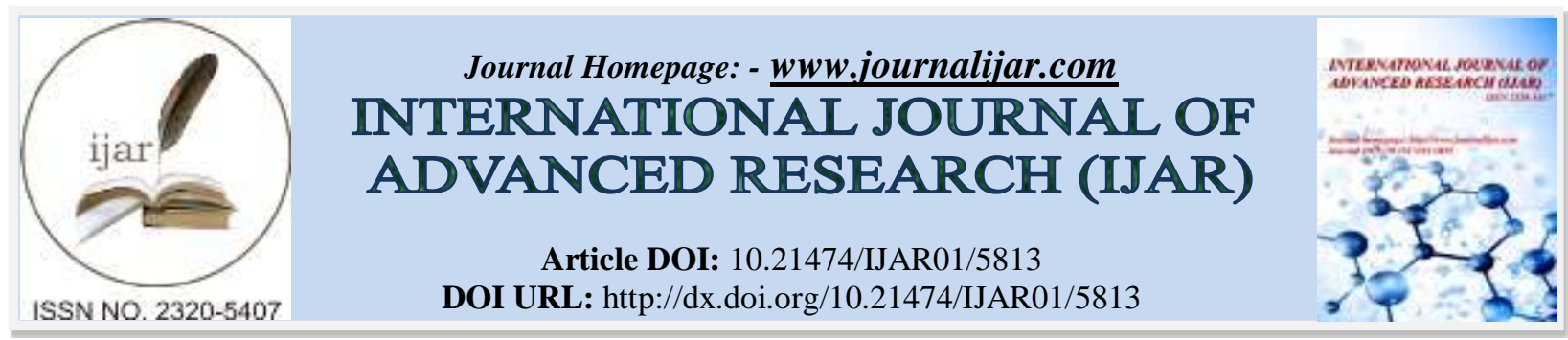

RESEARCH ARTICLE

\title{
VITEX NEGUNDO INDUCED PROTEIN CHANGES IN THE HAEMOLYMPH OF CALLOSOBRUCHUS CHINENSIS(COLEOPTERA:BRUCHIDAE.
}

Dr. M. Madhavi .

Department of Zoology, Nizam College, Osmania University, Hyderabad -500 001, Telangana, India.

\section{Manuscript Info}

Manuscript History

Received: 09 September 2017

Final Accepted: 11 October 2017

Published: November 2017

Key words:-

Vitex negundo, Callosbruchus chinensis, haemolymph, larvae, pupae.

\section{Abstract}

Callosobruchus chinensis is a Serious pest to agricultural crop produces infesting cereals, and many other food products, thus causing heavy damage to the food stuffs and useless for human consumption. Hence an attempt was made to control the stored products pest by using medicinal plant extract Vitex negundo. The protein content in the Haemolymph increased gradually in the larvae, pupae and the adults of C. chinensis, whereas in the Vitex negundo treated resultant larvae there was a prominent decrease in the protein content when compared with the controls.

Copy Right, IJAR, 2017,. All rights reserved.

\section{Introduction:-}

Proteins are the first biological factors making their manifestation during development. During metamorphosis of an insect, process like destruction of certain larval tissue and rejuvenation and remoulding of various tissues into adult. One is bound to take place involving synthesis and consumption of the macro molecules as well (Venugopal and Dinesh Kumar 1997). The Fat body tissue plays a key role in storage proteins. Storage proteins increased during successive stages of development (Kanost et al., 1990; Rajathi et al. 2010). Proteins are synthesized in the fat body and released into the haemolymph to be incorporated later into various organ including ovaries (Vallae1993).

Vitex negundo is used as a folk medicine. Medicinal properties of V.negundo have attracted the attention of plant physiologists and chemists. Vitex negundo is known to be insect repellent, insecticidal, larvicidal, mosquito repellant (Rajathi et al 2010) and antifeedant anti-bacterial, anti-fungal .The fat body protein content of $C$. chinensis, were studied in the V.negundo treated instars.

\section{Materials And Methods:-}

A rich standard culture of this insect was maintained in the laboratory on normal dietary medium composed of coarsely ground pulses, green gram inside a glass container at $26 \pm 1^{\circ} \mathrm{C}$ temperature and $65 \pm 5 \%$ Relative humidity.

\section{Plant material and Extraction of Vitex negundo crude leaf Extract:-}

Fresh leaves of the Vitex negundo $(\mathrm{VN})$ were collected, shade dried for a week and pulverized.The material was cold extracted in different solvents of petroleum ether, methanol, diethylether, and acetone separately at room temperature for $48 \mathrm{hrs}$ and the extract was evaporated to dryness under reduced pressure. The extract was weighed,re-dissolved in a known volume of acetone for making different concentrations of the extract. Preliminary studies showed that the methanol extract to be most effective among all the three solvents. Hence the follow up studies were conducted usi ng methanol extracts. 
Freshly moulted IV and V instar larvae were treated on the abdominal region with $1 \mu \mathrm{g} /$ larva of VN dissolved in $2 \mu 1$ of acetone with the help of Hamilton micro syringe. 50 larvae were treated each time and the experiments were replicated 5 times. Controls were treated with $2 \mu 1$ of acetone. After treatments a suitable time gap of 5 minutes was given and they were transferred into diet. The treated larvae were observed daily to note the changes. Fat body is dissected and rinsed free of haemolymph with Ringers solution. 10\% homogenate was prepared for the estimation of proteins and the protein was estimated by the method of Lowry et al 1951.

Statistical Analysis of the Data: The experimental data was analyzed statistically, mean and standard Deviation was calculated. The Haemolymph proteins was estimated in the control of IV instar larva, $\mathrm{V}$ instar larva, pupa and Adult.

\section{Results:-}

Estimation in control insects:-

\section{Haemolymph proteins:-}

IV instar larva:-

The protein content of the haemolymph of Callosobruchus chinensis was estimated in the IV instar larva; from the $1^{\text {st }}$ to the $7^{\text {th }}$ day. A gradual increase in protein content was observed. On the $1^{\text {st }}$ day of the IV instar $1.025 \pm 0.028$ $\mathrm{mg} / \mathrm{ml}$ of proteins was recorded in haemolymph. The value recorded on the $4^{\text {th }}$ day was $1.250 \pm 0.031 \mathrm{mg} / \mathrm{ml}$ which further increased to $2.0620 \pm 0.035 \mathrm{mg} / \mathrm{ml}$ on the $7^{\text {th }}$ day of the IV instar (Graph 1).

$\mathrm{V}$ instar

The $1^{\text {st }}$ day of the $V$ instar showed a value of $2.075 \pm 0.0353 \mathrm{mg}$ of protein $/ \mathrm{ml}$. It increased to $2.625 \pm 0.0369 \mathrm{mg} / \mathrm{ml}$ on the $6^{\text {th }}$ day. It futher increased to $2.9375 \pm 0.0375 \mathrm{mg} / \mathrm{ml}$ on the $9^{\text {th }}$ day and is slowly declined to $2.350 \pm 0.034 \mathrm{mg}$ of protein $/ \mathrm{ml}$ on the $10^{\text {th }}$ day (Graph1).

\section{Pupa:-}

It was observed that the protein content of haemolymph showed a steady decline. The recorded value on the $1^{\text {st }}$ day was $1.984 \pm 0.032 \mathrm{mg}$ of protein $/ \mathrm{ml}$ of haemolymph. Then, it steadily decreased to $0.985 \pm 0.023 \mathrm{mg} / \mathrm{ml}$ on the $7^{\text {th }}$ day (Graph 1).

\section{Adult:-}

The freshly emerged adult recorded a value of $0.724 \pm 0.024 \mathrm{mg} / \mathrm{ml}$ of haemolymph proteins. The value decreased to $0.321 \pm 0.019 \mathrm{mg} / \mathrm{ml}$ on the $2^{\text {nd }}$ day. There was a steady decrease and the last day of the adult recorded a value of $0.19 \pm 0.0154 \mathrm{mg} / \mathrm{ml}$ of haemolymph proteins (Graph 1).

Estimation of Haemolymph proteins in the larvae of Callosobruchus chinensis treated with extract of Vitex negundo

\section{Treated Insects:- \\ Haemolymph Proteins:- \\ IV instar larva:-}

The effect of extract of Vitex negundo on Callosobuchus chinensis larvae showed a decrease in haemolymph proteins when compared to the control.

The haemolymph proteins started increasing from the $3^{\text {rd }}$ day. The recorded value was $1.03 \pm 0.0281 \mathrm{mg} / \mathrm{ml}$. The value recorde on the $5^{\text {th }}$ day was $1.058 \pm 0.0284 \mathrm{mg} / \mathrm{ml}$ as compared to $1.642 \mathrm{mg} / \mathrm{ml}$ in control. The protein content on the $7^{\text {th }}$ day was $1.12 \pm 0.0289 \mathrm{mg} / \mathrm{ml} \quad($ Graph 1$)$.

\section{V instar:-}

The haemolymph protein content steadily increased till the $9^{\text {th }}$ day of the larva. The $1^{\text {st }}$ day of larva showed $1.124 \pm 0.0284 \mathrm{mg} / \mathrm{ml}$ of protein content. The protein content increased to $1.324 \pm 0.02951 \mathrm{mg} / \mathrm{ml}$ on the $5^{\text {th }}$ day of the $\mathrm{V}$ instar. It reached the maximum on the $9^{\text {th }}$ day, $1.381 \pm 0.032 \mathrm{mg} / \mathrm{ml}$ and decreased to $0.9254 \pm 0.029 \mathrm{mg} / \mathrm{ml}$ on the last day of the $\mathrm{V}$ instar (Graph 1).

\section{Pupa:-}

There was a steady decrease in the protein content of the pupa. The value recorded on the $1^{\text {st }}$ day was $0.921 \pm 0.0281 \mathrm{mg} / \mathrm{ml}$. It decreased to $0.201 \pm 0.0185 \mathrm{mg} / \mathrm{ml}$ on the last day of the pupa (Graph 1). 


\section{Adult:-}

The treated resultant adults' showed a decrease in haemolymph proteins when compared to control adults. The recorded value was $0.183 \pm 0.0189 \mathrm{mg} / \mathrm{ml}$ on the $1^{\text {st }}$ day and $0.11 \pm 0.014 \mathrm{mg} / \mathrm{ml}$ on the $2^{\text {nd }}$ day and $0.095 \pm 0.099 \mathrm{mg} / \mathrm{ml}$ on last day (Graph 1).

\section{Haemolymph proteins:- \\ Estimation in control insects:- \\ V instar:-}

The haemolymph proteins of the $\mathrm{V}$ instar of Callosobruchus chienesis estimated from the $1^{\text {st }}$ day of the instar to the $10^{\text {th }}$ day. On the $1^{\text {st }}$ day of the larva the protein content recorded was $2.075 \pm 0.034 \mathrm{mg} / \mathrm{ml}$. There was a slow increase in the haemolymph content, the values being $2.565 \pm 0.037 \mathrm{mg} / \mathrm{ml}$ on the $5^{\text {th }}$ day and $2.9375 \pm 0.0373 \mathrm{mg} / \mathrm{ml}$ on the $9^{\text {th }}$ day. There was a decrease on the $10^{\text {th }}$ day and the values recorded were $2.350 \pm 0.036 \mathrm{mg} / \mathrm{ml}$ (Graph 2).

\section{Pupa:-}

The recorded value on the $1^{\text {st }}$ day of the pupa was $1.984 \pm 0.031 \mathrm{mg} / \mathrm{ml}$. The steadily decreased and observed value on the $7^{\text {th }}$ day was $0.985 \pm 0.027 \mathrm{mg} / \mathrm{ml}$ (Graph 2).

\section{Adult:-}

The haemolymph protein content of the adult on the $1^{\text {st }}$ day was $0.724 \pm 0.0269 \mathrm{mg} / \mathrm{ml}$. The protein values recorded showed steady decrease and it was $0.19 \pm 0.013 \mathrm{mg} / \mathrm{ml}$ on the $5^{\text {th }}$ day (Graph 2).

Estimation of protein in treated resultant Callosobruchus chinensis larva.

Estimation in the treated insects

\section{V instar:-}

$\mathrm{V}$ instar treated with crude bulb extract and the resultant pupa and adult showed a decrease in protein content as compared to the control. The recorded value of haemolymph protein on the $1^{\text {st }}$ day was $2.075 \pm 0.034 \mathrm{mg} / \mathrm{ml}$. The $6^{\text {th }}$ day recorded a value of $2.399 \pm 0.036 \mathrm{mg} / \mathrm{ml}$ and it decreased to $2.041 \pm 0.0315 \mathrm{mg} / \mathrm{ml}$ on the last day of the $\mathrm{V}$ instar (Graph 2).

\section{Pupa:-}

There was a steady decrease in haemolymph proteins in the treated resultant pupa stage. The value recorded on the $1^{\text {st }}$ day was $1.062 \pm 0.029 \mathrm{mg} / \mathrm{ml}$. it decreased to $0.912 \pm 0.020 \mathrm{mg} / \mathrm{ml}$ on the $6^{\text {th }}$ day and further decreased to $0.541 \pm 0.018 \mathrm{mg} / \mathrm{ml}$ on the $7^{\text {th }}$ day (Graph 2).

\section{Adult:-}

The recorded value of haemolymph proteins on the $1^{\text {st }}$ day was $0.12 \pm 0.013 \mathrm{mg} / \mathrm{ml}$ which steadily decreased to $0.058 \pm 0.0031 \mathrm{mg} / \mathrm{ml}$ on the $4^{\text {th }}$ day and to $0.04 \pm 0.0026 \mathrm{mg} / \mathrm{ml}$ on the last day (Graph 2). 


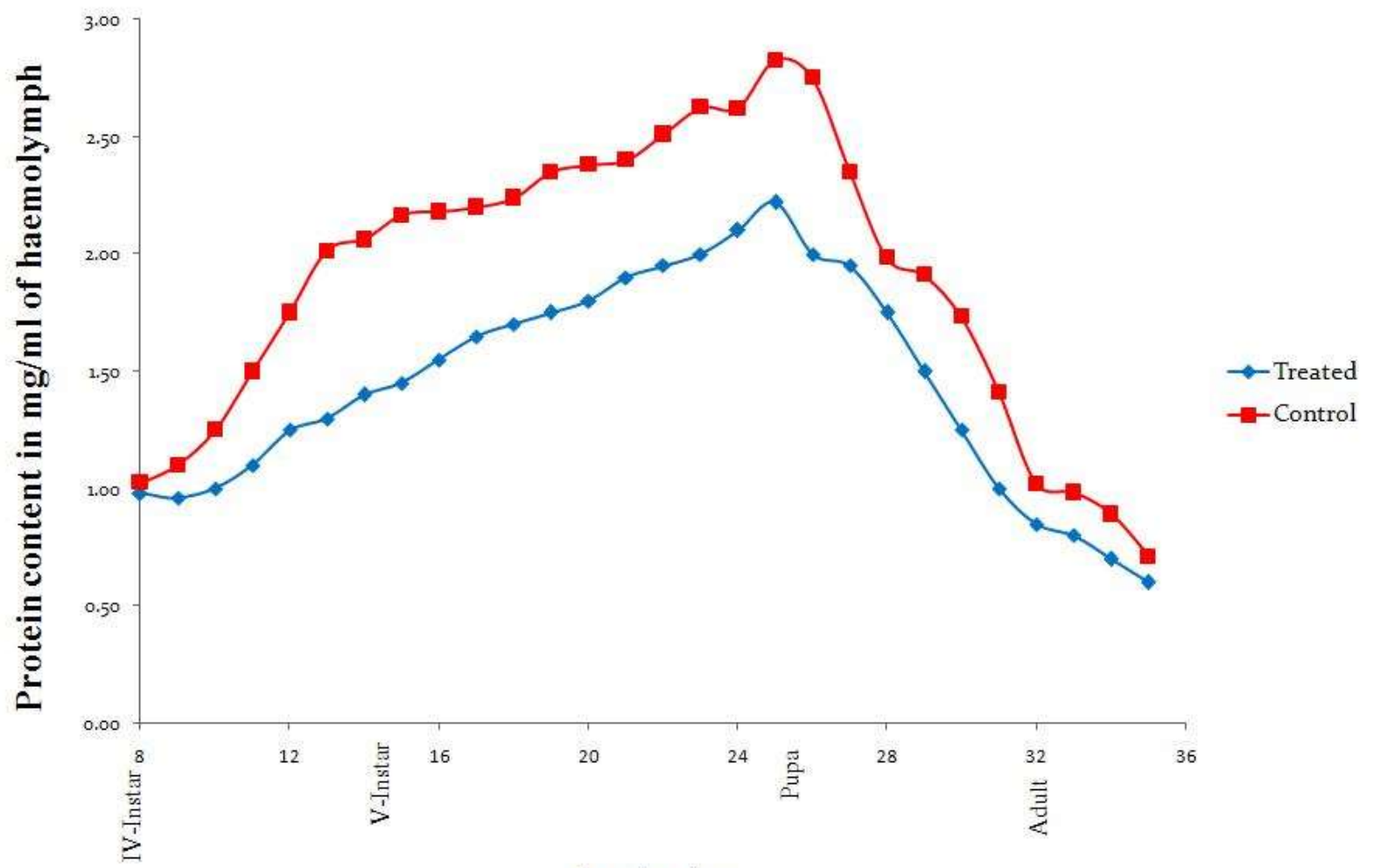

Age in days

Graph.1:- Quantitative changes in the protein content of the haemolymph of the IV, V instars, Pupa and Adult of the control insect and leaf extract of Vitex negundo treated IV instar insect during the development of Callosobruchus chinensis.

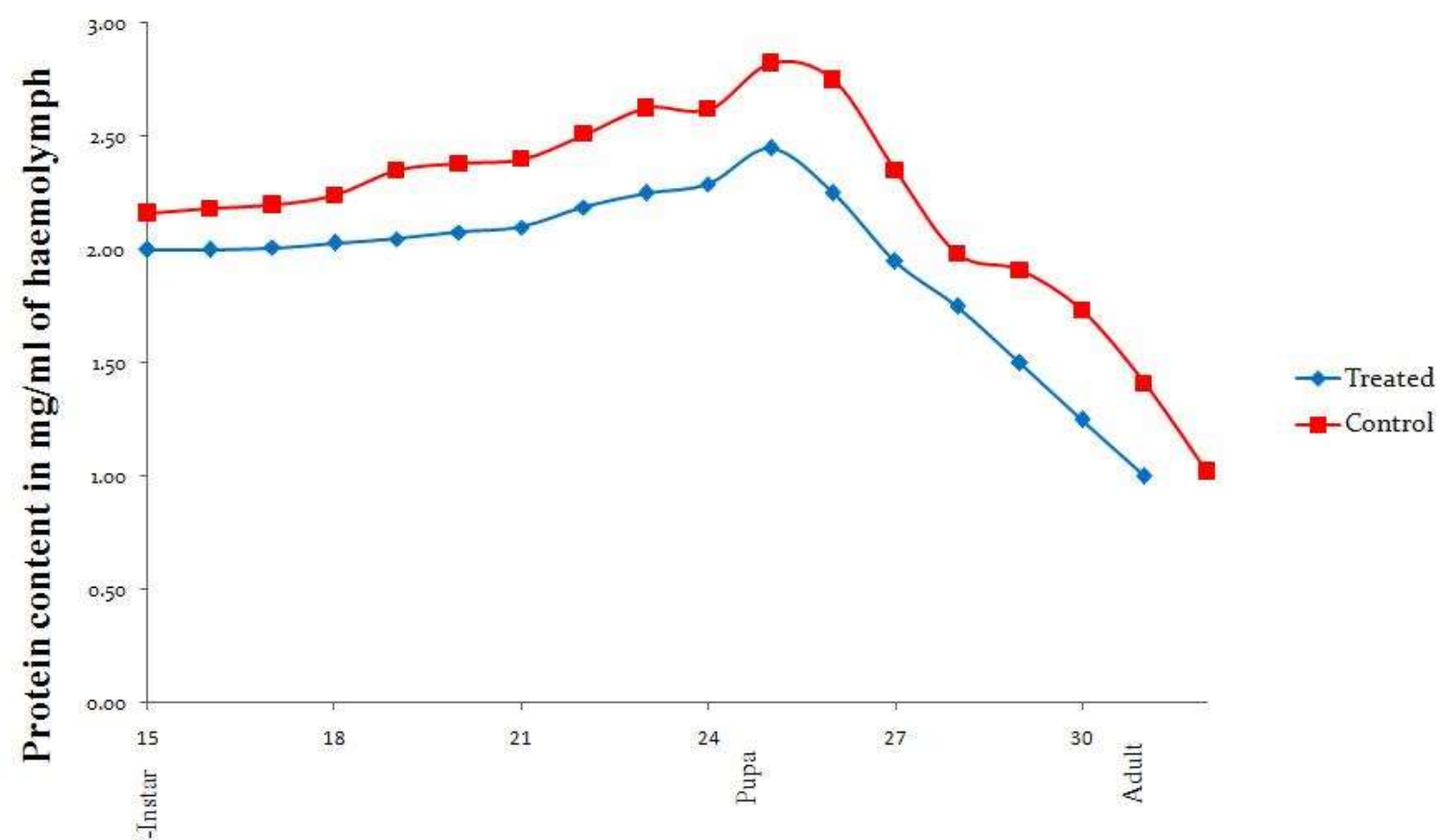

Age in days

Graph.2:- Quantitative changes in the protein content of the haemolymph of the V instar, pupae and Adult of the 
control insect and leaf extract of Vitex negundo treated V instar insect during the development of Callosobruchus chinensis

\section{Discussion:-}

C. chinensis $\mathrm{V}$ instar larva were treated with V.negundo treated resultants showed a decline in the protein content when compared to the control larvae. This may be due to the Vitex negundo functioning as a molting hormone analogue. As such it may interfere with neuroendocrine control of molting hormone synthesis. The protein content in the Haemolymph of $C$. chinensis exhibited a steady increase and the increase was markedly accelerated during the pre-pupal stage of development on the contrary, the protein concentration of the haemolymph increased gradually during larval development and reaches its highest value in the last instar larvae but decline during the pre-pupal and early pupal stages of development. Our results are in correlation with those of (Anitha et al., 2000; Banks and Malacoln, 1994) there was a gradual decline in the protein content of the treated resultant $C$. chinensis during the course of development. The disturbance in the hormonal imbalance inhibited protein synthesis in the ovary these results are in concurrence with that of the Raja et al. (1986). Administration of Vitex negundo controlled the stored product pest $C$. chinensis by influencing the moulting hormone. Thus, raising hope for its practical application in the stored grain pest management.

\section{References:-}

1. Anitha, H.R., Raja, S.S., Renuka, S. and Manjula, C., 2000. Effect of precocene-II on the protein changes in the haemolymph, fat body and Ovaries of Chilo partellus, during ontogenesis. Convergence, 2(1): 18-23.

2. Banks, G.A., Malacoln, G.A., 1994. Temporal pattern of RNA and Protein synthesis in the ovary of Aedes aegypti. J. Insects Physiol., 22: 299-397.

3. Dharmasri, M. G., Jayakody, J.R.A.C. and Galhena, G., 2003. Anti-inflammatory and analgesic activities of mature fresh leaves of Vitex negundo. J. Ethnopharmacol., 87: 199-202.

4. Kanost, M.R., Dawooga, J.K., Ryan, R.O, Husden M.D., Zeilger, R., 1990. Insect haemolymph proteins. Insect Physiol., 22: 299-397.

5. Ignacimuthu, S., 1998. Nature's ecofriendly arsenal of pesticides. Curr. Sci., 74: 1037.

6. Lowry, O.H., Rosebrough,, J..J., Farr, A.L., Randall, R.J., 1951. Protein measurement with the folin phenol reagent. J. Biol. Chem., 193: 263-275.

7. Umamaheshwari, M., Ashok Kumar, K and Somasundaram, A., 2007. Xanthine oxidase inhibitory activity of some Indian medical plants. J. Ethnopharmacol. 109(3): 547-551.

8. Raja, S.S., Thakur, B., Kishen, R., and Kaur, A. 1986. Selective accumulation of haemolymph proteins by fat body during larval pupal transformation of Chilo partellus. Entomol. Bohemoslov., 154:205-208.

9. Rajathi. A., Pandiaajan J., Krishnan,M., 2010. Effect of RH-2485 on the development, metamorphosis and synthesis of major proteins in female silkworm Bombyx mori. Biologia, 65(5): 903-913.

10. Vallae, D., 1993. Vitellogenesis in insects and other groups A review, Membr Inst. Oswald, Cruz, 88: 1-26.

11. Venugopal, K.J., Dinesh Kumar, 1997. Electrophoretic studies on the development profiles of protein in Haemolymph, Fat body and ovary of red cotton bug, Dysdercus Koenigii. Entomon 22: 185-191. 